JURNAL ABDI INSANI UNIVERSITAS MATARAM

Volume 8, Nomor 2, Agustus 2021

\title{
PENGELOLAAN KONSERVASI KELELAWAR DIMASA PANDEMI COVID 19
}

\section{Management of Bat Conservation during the Covid Pandemic 19}

\section{Safriyanto Dako ${ }^{* 1}$, Suparmin Fathan ${ }^{1}$, Fahria Datau ${ }^{1}$, Nibras K. Laya ${ }^{* * 1}$, Netty Icno Ischak ${ }^{* * * 2}$, Stevandi Sampow ${ }^{3}$, Ismail Baderan ${ }^{3}$}

${ }^{1}$ Program Studi Peternakan Universitas Negeri Gorontalo, ${ }^{2}$ Program Studi Kimia Universitas Negeri Gorontalo, ${ }^{3}$ Program Sarjana Peternakan Fakultas Pertanian Universitas Negeri Gorontalo, Indonesia

\section{Jl. Prof. Dr. Ing. Bj. Habibie. Kab. Bonebolango}

Korespondensi: "sdako@ung.ac.id, ${ }^{* * *}$ nettyischak@gmail.com, ${ }^{* *}$ nibraslaya@ung.ac.id

(Tanggal Submission: 2 Juni 2021, Tanggal Accepted : 19 Agustus 2021)

\section{Keyword : \\ Kelelawar, Konservasi berkelanjutan, Pengelolaan penangkapan, dan Pengelolaan area konservasi}

\section{Abstrak :}

Pengelolaan konservasi kelelawar di wilayah In-situ dilakukan sebagai upaya penyelarasaan antara nilai ekonomi dan nilai konservasi kelelawar pada masa pandemic Covid 19, sehingga memberi harapan baru perbaikan ekonomi bagi kelompok pemanfaat kelelawar dan keberlanjutan konservasi. Kegiatan pengabdian kepada mayarakat bertujuan untuk menerapankan tatakelola konservasi kelelawar di wilayah In-situ dimasa Pandemi COVID-19. Pendekatan pengelolan melalui model PRA (Participatory Research Appraisal). Analisis deskriptif digunakan untuk menggambarkan pengelolaan konservasikelelawar. Pengelolaan dilakukan untuk kegiatan penangkapan sampai pemasaran satwa Kelelawar. Pembatasan jumlah penangkap dalam setiap trip penangkapan (3-4 orang/kelompok ) dan frekuensi penangkapan di batasi 4 kali/bulan. Perubahan tatakelola di masa pandemic covid 19 dilakukan pada pertengahan tahun 2020, karena adanya permintaan kelelawar yang meningkat hingga 90-100\% dari tahun sebelumnya, Harga kelelawar naik menjadi Rp 40.000-50.000/kg dan penambahan jumlah penangkap (5-6 orang/kelompok). Perubahan tatakelola konservasi kelelawar selama masa pandemic Covid 19 meningkatkan kesadaran tentang Covid 19, meningkatkan indeks kelimpahan dan meningkatkan pendapatan.

Panduan sitasi / Citation guidance (APPA $7^{\text {th }}$ edition) :

Dako, S., Fathan, S., Datau, F., Laya, N. K., Ischak, N. I., Sampow, S., \& Baderan, I. (2021). Pengelolaan Konservasi Kelelawar Dimasa Pandemi Covid-19. Abdi Insani, 8 (2), 216-222. http://doi.org/10.29303/abdiinsani.v8i2.401 


\section{PENDAHULUAN}

Desa Olibu terletak diwilayah timur pesisir pantai selatan Kabupaten Boalemo, Desa ini dijadika wilayah konservasi kelelawar yang dikelola oleh Pemerintah Desa dan bekerjasama Universitas Negeri Gorontalo melalui Program Pengembangan Desa Mandiri. Karena potensi kelelawar yang mentap sepanjang tahun. Jenis kelelawar yang hidup di hutan mangrove adalah Pterepthus Alecto dan Accerodon selebensis (Dako et al., 2020; Ischak et al., 2020).

Sejak di temukannya Virus Corona (Bat Cov) pada kelelawar (Febriani, et al 2018) dan awal terjadinya pandemic hingga saat ini, memberikan nuansa barudalam pola hidup masyarakat. Dampak pandemic Covid-19 ini juga berdampak terhadap aktivitas masyarakat, dimana aktivitas kegiatan diluar rumah menjadi berkurang, sehingga kegiatan ekonomi menjadi terhambat.

Menurut Gugus Penanganan COVID Gorontalo (2021) kasus covid yang terjadi di Gorontalo, 4632 (positif),4316 (sembuh), 125 (Meninggal) terus meningkat walaupun peningkatan yang terjadi tidak seperti diwilayah lainnya seperti dipulau jawa, namun adanya kebijakan nasional selama masa pandemic covid 19, sangat berpengaruh terhadap aktivitas masyarakat.Kondisi ini juga berpengaruh pada masyarakat dan Kelompok Pemanfaat Kelelawar di kawasan konservasi di desa Olibu.

Pada awal pandemi COVID-19jumlah permintaan kelelawar meninggkat dibanding dengan kondisi normal, dan juga harga pengambilan kelelawar di tingkat penangkap terjadi kenaikan $100 \%$ (Rp. $40.000-\mathrm{Rp} .50 .000 / \mathrm{kg}$ ) dan permintaan jumlahkelelawar yang diminta oleh pedagang pengumpul naik hingga $150 \%$. Kondisi ini secara spontan merubah perilaku anggota kelompok pemanfaat kelelawar yang bersentuhan langsung dengan penangkapan kelelawar, namun adanya aturan kelompok dan PEMDES tentang pembatasan penangkapan kelelawar sehingga membatasi gerak anggota dan kelompoknya.,disisi lain kebutuhan ekonomi tidak dapat diabaikan. Tekanan kondisi pandemic yang dihadapi oleh kelompok pemanfaat kelelawar menyebabkan persoalan menjadi dilematis, sehingga perlu dilakukan kebijakan bersama Pemerintah Desa Olibu, Kelompok Pemanfaat Kelelawar dan TIM Progaram Pengembangan Desa Mandiri (PPDM) Universitas Negeri Gorontalo bersama merumuskan langkah kongkrit dalam mengatsi permasalahan yang terjadi yaitu pengelolaan Konservasi Kelelawar selama masa Pandemi Covid-19. Pengelolaan konservasi kelelawar di wilayah In-situ dimasa pandemic menjadi penting untuk diketahui, sebagai upaya penyelarasaan antara nilai ekonomi dan nilai konservasi kelelawar, sehingga memberi harapan baru perbaikan ekonomi dalam keterpurukan ekonomi selam masa pandemic Covid 19 dan keberlanjutan konservasi kelelawar. Tujuan Pengabdian ini untuk melakukan perubahan tatakelola diwilayah konservasi kelelawar dimasa Pandemi COVID-19.

\section{METODE PELAKSANAAN}

Pengenlolaankawasan konservasi ini dilaksanakan di Desa Olibu, Kecamatan Paguyaman Pantai, Kabupaten Boalemo, Provinsi Gorontalo, Sasaran utama adalah masyarakat, 
Kelompok Pemanfaat Kelelawar, Pemerintah Desa. Pelaksanaan perubahan pengelolaan di masa pandemic covid 19, dilakukan dalam 2 tahapan yaitu Tahap pengelolaan penengkapan, terdiri atas: Penetapan titik Penangkapan (1), Penggunaan Mis Net dalam penangkapan (2), kesepakatan perubahan jumlah tangkapan dan frekwensi penangkapan (3), Penetapan jumlah penangkap dalam kelompok (5), Pengunaan karantina untuk menampung kelelawar (6), Sortasi kelelawar (7), dan Pemasaran kelelawar (8). Tahap kedua adalah pengeloaan ruang konservasi di masa pandemic covid 19 terdiri atas Penetapan dan perluasan batas zona larangan (1), Penambahan titik penangkapan (2), dan perluasan batas zona insitu dan exsitu (3).

Metode pendekatan melalui PRA sesuai yang di sarankan, (Dako et al., (2020; Wirawan et al., (2021)). Penerapan metode PRA untuk meningkatkan partispasi anggota kelompok pemanfaat kelelawar dalam memecahkan permasalahan yang di hadapi selama perubahan pengelolaan di kawasan Konservasi di masa pandemic covid 19. Analisis Deskriptif digunakan untuk menggambarkan pengelolaan tata kelola konservasi di masa pandemic covid 19.

\section{HASIL DAN PEMBAHASAN}

Pengelolaan konservasi merupakan pengaturan wilayah konservasi kelelawar,terfokus pada pengelolaan penangkapan,dan pengelolaan area/ruang konservasi kelelawar.Pengelolaan konservasi kelelawar disajikan pada tabel 1

Tabel 1. Pengelolaan konservasi kelelawar selama masa pandemic

\begin{tabular}{|c|c|c|c|}
\hline No & Pengelolaan & Sebelum Covid19 (2019) & Pandemi Covid-19 (2020) \\
\hline A & Pengelolaan Penangkapan & & \\
\hline 1 & Indeks kelimpahan kelelawar & 7.57 & 15.47 \\
\hline 2 & Jumlah Penangkap & $\begin{array}{ll}3-4 & \text { orang } \\
\text { /trip/kelompok } & \end{array}$ & 5-6 orang /trip/kelomok \\
\hline 3 & Jumlah Tangkapan & $\pm 10 \mathrm{~kg} /$ trip & $\pm 20 \mathrm{~kg} /$ trip \\
\hline 4 & Frekuensi penangkapan & 4 kali/bulan & 4 kali/bulan \\
\hline 5 & Waktu penangkapan & Malam hari & Malam hari \\
\hline 6 & Harga jual/kg & Rp. $10.000-15.000 / \mathrm{kg}$ & Rp. $40.000-50.0000 / \mathrm{kg}$ \\
\hline 7 & Frekuensi Pemasaran & 2 kali/bulan & 3 kali/bulan \\
\hline 8 & Sortasi Kelelawar & Dilakukan & Dilakukan \\
\hline 9 & Karantina kelelawar & Dilakukan & Dilakukan \\
\hline B & Pengelolaan Ruang konservasi & & \\
\hline 1 & Zona Larangan & 2 ha (Manggrove) & 4 ha (Manggrove) \\
\hline 2 & Zona Penangkapan & 20 ha & 40 ha \\
\hline 3 & Titik penangkapan & 5 titik & 7 titik \\
\hline 4 & Alat penangkapan & Misnet & Misnet \\
\hline 5 & Penanaman zona insitu & Dilakukan & Dilakukan \\
\hline 6 & Tempat sortasi & ada & Ada \\
\hline 7 & Pos pengawasan & 1 pos & 1 pos \\
\hline 8 & Tempat karantina & 1 bangunan & 1 Bangunan \\
\hline
\end{tabular}

Keterangan: Data olahan 2021 


\section{Pengelolaan penangkapan Kelelawar}

Berdasakan Tabel 1 pengelolaan penangkapan kelelawar diwilayah konservasi selama tahun 2019 diatur berdasarkan permasalahan penyelamatan potensi satwa kelelawar, habitat hutan mangrove, yang disebabkan perebutan wilayah tangkapan, penggunaan alat tangkap yang berbeda antara penangkap yang berada di kawasan konservasi dan penangkap yang berasal dari luar desa Olibu. Perubahan pengelolann pada masa pandemic Covid 19 juga melibatkan kelompok, masyarakat dan PEMDES berdasarkan kondisi yang terjadi. Pengaturan jumlah tangkapan diatur dan penggunaan Mis Net dalam wilayah konservasi kelelawar berdasarkan kesepakatan kelompok pemanfaat kelelawar, Pemerintah Desa Olibu (Ischak et al., 2020; Dako et al., (2021), sehingga secara langsung keterlibatan partisipasi kelompok dan masyarakat pemanfaat jelas tergambarkan. Partisipasi masyrakat merupakan proses ketika kelompok dan masyarakat (sebagai individu, kelompok dan masyarakat yang berkepentingan) berperan dan ikut memepengaruhi perencanaan, proses pelaksanaan, dan mengawasi secara langsung, yang pada akhirnya akan berdampak peningkatan nilai ekonomi bagi kehidupan mereska (Sumarto \& Hetifah (2009); Peranginangin (2014)).

Perubahan pengelolaan penangkapan kelelawar awal pandemic Covid 19 di Indonesia. Proses penangkapan hingga pemasaran satwa kelelawar ditriwulan I-II terjadi penghentian, Kondisi ini disebabkan pembatasan aktivitas secara Nasional, sehingga berlaku juga pembatasan aktivitas diwilayah konservasi, penyebab lain adalah kelelewar dianggap sebagai induk semang dalam penyebaran virus Corona, walaupun menurut Andersen et al.,(2020) dan Gralinski \& Menachery, (2020), SARS-CoV-2 tidak langsung menular pada manusia, infeksi dari kelelawar ke manusia belum terbukti, karena terdapat perbedaan struktur receptor binding domain (RBD) antara SARS-CoV-2 dengan CoVs pada kelelawar. Perubahan ini menyebabkan pendapatan ekonomi kelompok pemanfaat menjadi berkurang.

Perubahan pengelolaan penangkapan kembali terjadi di ditriwulan III. Awalnya pembatasan jumlah penangkap. Ditriwulan III dimasa pandemic Covid 19 di izinkan penangkap sebanyak 5-6/orang/tripe/kelompok.Jumlah tangkapan menjadi \pm 20 $\mathrm{kg} /$ trip/anggota kelompok, dengan frekuensi penangkapan tetap 4 x sebulan, hal ini dilakukan karena permintaan jumlah kelelawar dan harga kelelawar yang meningkat $100 \%$ pada masa pandemic.Kegiatan penangkapan kelelawar tidak diperbolehkan pada siang hari namun di $2 / 3$ malam. Penggunaan Mis Net dalam proses penangkapan menjadi kewajiban dalam menangkap kelelawar.Menurut Santoso et al., (2020), Kelelawar ditangkap dengan jaring kabut dimulai dari pukul 18.00-22.00, sedangkan Dako et al., (2021), penangkapan kelelawar di wilayah konservasi kelelawar dilakukan pada malam hari dari jam 02.00-05.00 am (dini hari) saat kelelawar memasuki hutan mangrove untuk beristrahat.

Penerapan sortasi dan karantina dalam proses penangkapan kelelawar dilakukan sebagai upaya menjaga kelestarian kelelawar. Dibagian sortasi ini, kelelawar pregnant (bunting), Kelelawar bersama anaknya dan Kelelawar betina anak dilepas kembali kehabitatnya. Proses recording juga dilakukan saat penimbangan. Proses karantina dilakukan untuk memulihkan kondisi stress kelelawar sebagai akibat proses penangkapan yang 
dilakukan, maka dilepaskan kembali ke habitat. Pelepasan kembali kelelawar kehabitatanya, jika kondisinya telah kembali normal. Salah satu ukuran sehat dan tidak stress atau ketakutan, maka kelelawar akan berperilaku berperilaku normal seperti membersihkan tubuh (grooming) dan berpasangan (Allogrooming). Grooming pada kelelawar di penangkaran dilakukan dengan

cara menjilat, menggaruk-garuk, dan mengusap-usap bagian tubunya (Ramlah et al., 2021). Model pengelolaan penangkapan kelelawar diwilayah konservasi disajikan dalam gambar 1.

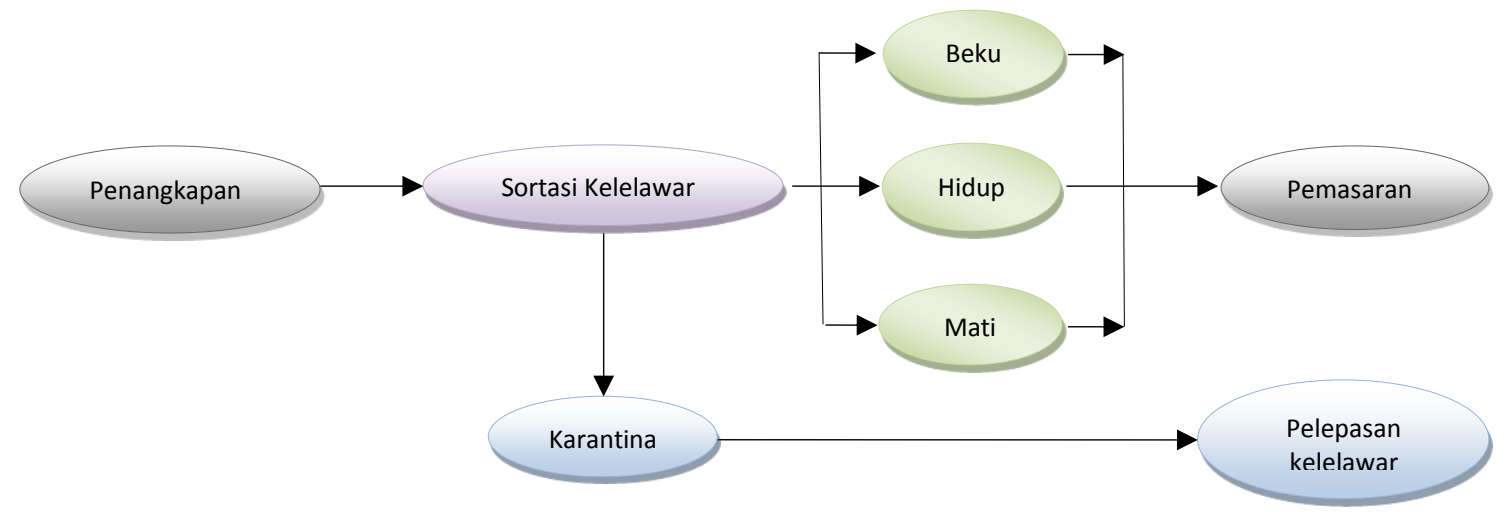

Gambar 1 Model Pengelolaan penangkapan satwa Kelelawar di wilayah Konservasi

Proses pemasaran sebelum masa pandemic, kelelawar di jual dalam keadaan hidup, selama masa pandemic kelelawar dijual tidak dalam keadaan hidup, namun dalam keadaan mati dan beku. Jumlah satwa kelelawar yang dipasarkanbergantung dari jumlah hasil tangkapan. Pemasaran kelelawar dilakukan melalui pemesanan langsung dan pedagang pengumpul menjemput langsung kedesa atau penagkap kelelawar.

Menurut Lasaharu \& Boekoesoe 2(020), Pemasaran ternak atau hewan biasanya melalui pemesanan atau dijemput langsung oleh pedagang ditempat produsen atau peternak yang ingin menjual ternaknya.

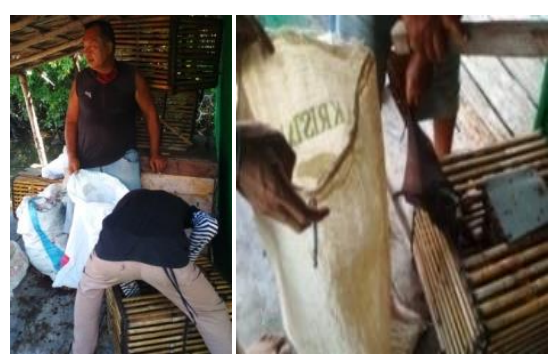

a

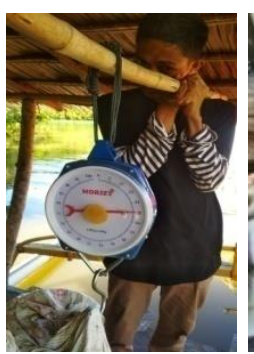

b

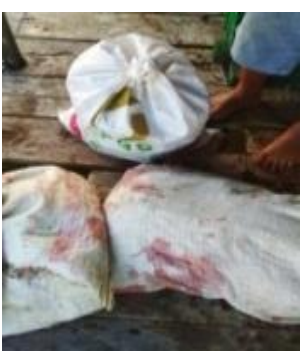

C

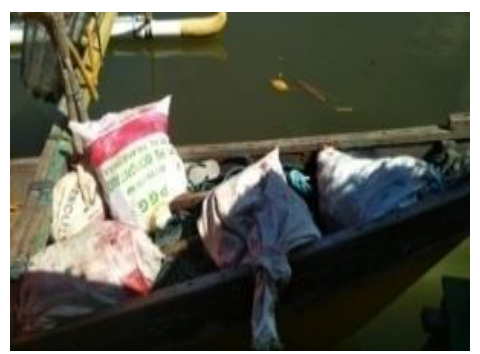

d

Keterangan :

a. Kelelawar di matikan, b. Penimbagan, c. Pengepakan, d. Pengangkutan/pengiriman Gambar 2. Pemasaran kelelawar

\section{Pengelolaan Ruang konservasi}

Pengelolaan ruang konservasi (tabel 1)adalah pengaturan area konservasi kelelawar, area ini merupakan habitat utama dari kelelawar. Perubahan dilakukan selama masa pandemic Covid 19,terutama pada zona larangan dihutan mangrove seluas 4ha, 
danpenetapan titik penangkapan diwilayah in situ menjadi 7 titik penangkapan(Gambar 1).Perluasan area larangan dilakukan untuk menjaga dan memperluas kesempatan kelelawar untuk berkembangbiak., selain itu memperluas wilayah penanaman tanaman pakan kelelawar., sehingga tercipta daya dukung lingkungan yang stabil bagi kelelawar, dan mencegah erosi disaat musim penghujan.

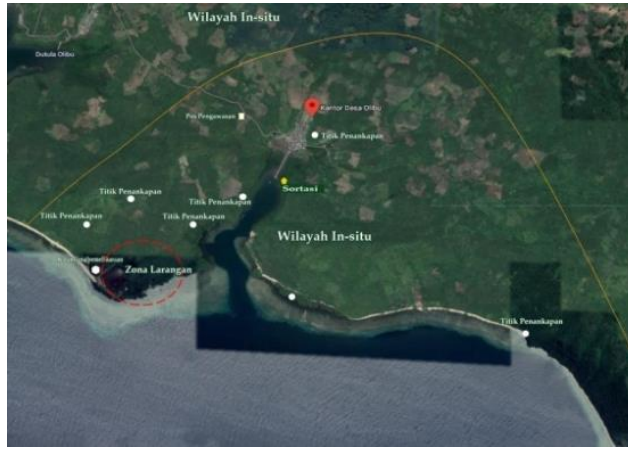

a

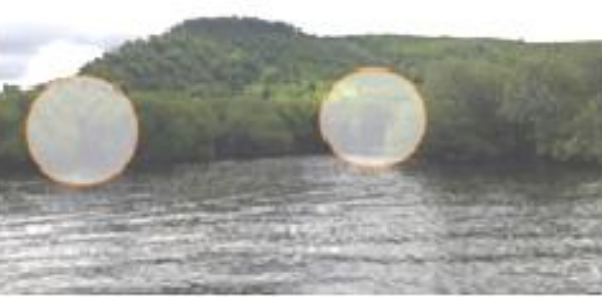

b

Keterangan:

a. titik penangkapan saat pandemic

b. lokasi penangkapan (titik tambahan)

Gambar 3. Wilayah Konservasi Kelelawar (In-stu dan Ex-situ)

Kelelawar memiliki kerentan tinggi terhadap kerusakan habitat dan hilangnya daya dukung lingkungan, disebabkan sifat dan produktivitasnya rendah (kelelawar sekali melahirkan hanya 1 ekor, waktu asuh yang panjang. Sehingga adaptasi untuk bertahan hidup pada habitat yang stabil dan mudah diprediksi; serta populasi yang dipertahankan untuk tetap berada dalam daya dukung lingkungannya (Kunz \& Pierson, (1994); Purvis et al., (2000)).

\section{KESIMPULAN DAN SARAN}

Kesimpulan

Penerapan perubahan tatakelola diwilayah konservasi dimasa pandemic covid 19 dilakukan untuk mengatur proses penangkapan, ruang lestari kelelawar, dan meningkatkan indeks kelimpahan kelelawar serta meningkatkan nilai tambah ekonomi bagi kelompok pemanfaat kelelawar di wilayah Konservasi kelelawar.

Saran

Perlu adanya kerjasama yang lebih luas dengan Instansi terkait menjadikan potensi kawasan konservasi kelelawar menjadi Kawasan wisata Alam atau wisata pendidikan

\section{UCAPAN TERIMAKASIH}

Ucapan terimakasih disampaikan kepada Kementerian Ristek Dikti melalui Direktur Lembaga Penelitian dan Pengabdian atas Pendanaan Program Pengembagan Desa Mandiri (PPDM). Ucapan terimakasih juga kepada Ibu Mastin Bouti (Kepala Pemerintah Desa Olibu), Suleman Daima (Ketua LPM Desa Olibu), Aparat desa dan masyarakat desa Olibu, dan mahasiswa KKS UNG 2020 atas kerjasama dalam program penbadian pada masyarakat. 


\section{DAFTAR PUSTAKA}

Andersen, K. G., Rambaut, A., Lipkin, W. I., Holmes, E. C., \& Garry, R. F. (2020). The proximal origin of SARS-CoV-2. Nature Medicine, 26(4), 450-452.

Dako, S., Laya, N. K., Ischak, N. I., \& Yusuf, F. M. (2021). Mist Net Dan Teknik Penangkapan Kelelawar. Dharmakarya, 10(1).

Dako, S., Laya, N. K., Ischak, N. I., Yusuf, F. M., Djafar, F. H., \& Daima, S. (2020). Implementasi Konservasi Kelelawar Berkelanjutan Di Desa Olibu Provinsi Gorontalo. Abdi Insani, 7(1), 9-13. https://doi.org/https://doi.org/10.29303/abdiinsani.v7i1.293

Gralinski, L. E., \& Menachery, V. D. (2020). Return of the Coronavirus: 2019-nCoV. Viruses, 12(2), 135.

Ischak, N. I., Yusuf, F. M., Dako, S., K., L. N., Sampow, S., M.J., N., Lapian, H. F. N., \& H., D. F. (2020). Penerapan Pupuk Organik Cair (POC) dari Guano Kelelawar bagi Kelompok pemanfaat Kelelawar. Prosiding Seminar Hasil-Hasil Pengabdian Masyarakat.

Kunz, T. H., \& Pierson, E. D. (1994). Bats of the world: an introduction. Pages 1-46 in R. W. Nowak, editor: Walker's bats of the world. Baltimore (USA) : John Hopkins University Press.

Lasaharu, N., \& Boekoesoe, Y. (2020). Analisis Pemasaran Sapi Potong. Jambura Journal of Animal Science, 2(2), 62-75.

Peranginangin, L. S. U. (2014). Partisipasi masyarakat dalam pengelolaan kawasan konservasi. Jurnal Kebijakan Dan Administrasi Publik, 18(1), 66-78.

Purvis, A., Gittleman, J. L., Cowlishaw, G., \& Mace, G. M. (2000). Predicting extinction risk in declining species. Proceedings of the Royal Society of London - Series B: Biological Sciences, 267:1947-1952.

Ramlah, R., Ransaleleh, T. A., \& Nangoy, M. J. (2021). Tingkah laku grooming kelelawar Pteropus alecto di penangkaran ex-situ. ZOOTEC, 41(2), 389-397.

Santoso, E., Nurcahyani, N., Rustiati, E. L., \& Ariyanti, E. S. (2020). Studi Keragaman Kelelawar Di Perbatasan Taman Nasional Way Kambas Dengan Desa Labuhan Ratu VII. Journal of Tropical Upland Resources. J. Trop. Upland Res., 2(2), 222-229.

Sumarto, \& Hetifah, S. J. (2009). Inovasi, Partisipasi, dan Good governance 20 Prakarsa Inovatif dan Partisipatif di Indonesia. Jakarta (ID) : Yayasan Obor Indonesia.

Wirawan, P. E., Arianty, A. A. S., Dewi, I. G. A. M., Susanti, L. E., \& Sari, K. R. T. (2021). Model Participatory Rural Appraisal (PRA) untuk Pemberdayaan Perempuan Berbasis Pendampingan Melalui Pelatihan Cake Decoration di Desa Batuan. Jurnal Abdi Masyarakat, 1(1), 11-21. 